\begin{tabular}{cc}
\hline & International Journal of Engineering \& Technology, $7(1.3)(2018)$ 104-111 \\
SPC & International Journal of Engineering \& Technology \\
\hline
\end{tabular}

\title{
Modeling, control, and implementation of the soft switching dc-dc converter for battery charging/discharging applications
}

\author{
J. Barsana Banu ${ }^{1 *}$, M. Balasingh Moses ${ }^{3}$ \\ ${ }^{1}$ Research Scholar, Department of EEE, University College of Engineering, Trichirapalli-620024, India \\ ${ }^{2}$ Assistant Professor \& HOD, Department of EEE, University College of Engineering, Trichirapalli-620024, India \\ *Corresponding author E-mail: barsanajamal@gmail.com
}

\begin{abstract}
This paper presents a soft switching bidirectional buck-boost converter for battery charging and discharging systems. The proposed method comprises of Inductance Capacitance Diode combination of the bidirectional dc-dc converter with one more electric switch is presented to accomplish high efficiency, high conversion ratio and maximum output power compared to the other bidirectional converters. It works in both steps up and steps down conversions. The proposed converter has alleviated the switching stress problems in the conventional bidirectional dc-dc converter. It suppresses the switching losses by zero voltage and zeroes current turn ON and OFF all switches. The complete steady-state analysis of the proposed bi-directional converter has described with its operating modes. Design consideration of parameters also presented to realize the converter characteristics. The switching stress on the power semiconductor devices is given, and the comparisons between the proposed technique and other bidirectional converters are illustrated with some results. Finally, the experimental prototype of $20 \mathrm{kHz}, 315 \mathrm{~W}$ output power converter developed, and its feasibility verified through computer simulation results.
\end{abstract}

Keywords: Battery Charging/Discharging; Bidirectional Power Flow; Steady-State Analysis; Zero Current Switching (ZCS); Zero Voltage Switching (ZVS).

\section{Introduction}

In recent years, due to the energy crisis and atmospheric contamination, the renewable energy is extensively treasured and employed. The renewable-energy source (RES), such as the fuel cells and the photovoltaic cells generally produces very low output voltage. Therefore, it is essential to combine a number of PV panels and fuel cells in shunt or series type to generate high-output voltage. However, the efficiency being reduced with growing up of the number of cells. Thus in order to provide high voltage as output, step up dc-dc converter has extensively applied for RES. Several topologies of the boost converter have been studied based on resonant switching, coupled inductor, etc. and so on [1-5]. The output voltage cannot be much higher than the input voltage due to the effect of parasitic elements in the conventional boost converter. Furthermore, boost converter operated with a maximum duty ratio leads to decrease the overall efficiency with increased Electro-Magnetic Interference (EMI) due to the reverse recovery troubles in the anti parallel diode. Many researchers have been established to improve the efficiency of the dc-dc converter. Step down dc-dc converters are constantly used as MPPT systems to avoid the power losses created in PV generation systems [6-8] For effective battery charging and discharging system, uninterruptible and auxiliary power supplies, several bidirectional $\mathrm{dc}-\mathrm{dc}$ converters have been proposed. Bidirectional dc-dc converters with high-frequency isolation transformer based topologies [9-12] are most likely structures. However, these are suffering from switching losses, and current stresses due to more power semicon- ductor switches, as they need additional snubber and auxiliary circuits in order to reduce the losses incorporated in the switches. Nowadays, the significance of the transformer less bidirectional dc-dc converter is being improved because of uncomplicated structure, low cost, a lesser amount of switches and trouble-free control than the transformer based bidirectional DC-DC converter topologies to achieve high efficiency. Many topologies of a non isolated bidirectional dc-dc converter have been developed [1314].

However, the conventional non isolated bidirectional dc-dc converters are suffered from large switching losses, the long reverse recovery time of anti-parallel diodes and resonant current sensing problem. Adaptive phase shift (PS) techniques based converters are introduced to reduce switching losses [15]. Although a look up table is developed to control the auxiliary switch, which creates resonant current trouble. Still power loss is increased due to the presence of auxiliary switch and diode [16]. The interleaved buck boost converter is described to reduce switching losses, current and voltage ripples and reduction of switches and diodes by connecting switching capacitor in [17].

In order to obtain high conversion ratio, cascade connection of a magnetically coupled interleaved buck boost converter is employed to reduce input and output ripple currents [18-21]. Pulsewidth-modulation (PWM) and adaptive-conversion-ratio (ACR) phase generator are proposed to achieve high gain and efficiency to the cascaded boost converter [22].In order to realize a high accuracy and quick response for suitable design and control; it is required to have an accurate model of the bidirectional converter. Hence, mathematical modeling of the bidirectional dc-dc convert- 
er is proposed in [23]. Steady state and transient analysis of distinct modes of a bidirectional converter are studied [24].

Load voltage is controlled by fine-tuning of the duty cycle and this non-inverting synchronous buck-boost DC-DC converter function at any voltage greater or less than the given input voltage without changing its polarity is described in [25]. Capacitor-diode voltage multiplier and some passive components have been added with conventional dc-dc converter to provide high step up and step down voltage conversion ratios and obtain maximum efficiency at light load is described in [26-27]. Optimized switching pattern is offered to achieve ZVS turn on and ZVS turned off as well as high-voltage gain can be reached, but soft switching is not achieved for all switches [28]. Auxiliary resonant commutated pole applied to a bidirectional dc-dc converter is introduced [29] to attain full soft switching and clear waveforms for all the resonating components.

This paper proposes a simple and cost effective non-dissipative LCD clamp with an active switch bidirectional DC-DC converter to achieve maximum efficiency, reduces switching losses by zero voltage turn on and turn off of all semiconductor switches and applicable to high-power conversion. This Non-dissipative LCD (inductance capacitance diode) snubber recycles the energy absorbed from either input or output side, and it circulates throughout the switching period. The advantages of the proposed converter topology are high reliability, simple structure, low-cost and high efficiency. With these characteristics, power can be exchanged from the input voltage source to the output DC battery and vice versa happens with maximum efficiency.

The paper is arranged as follows: Section 2 presents the proposed circuit configuration. Operating principle of the proposed circuit with distinct modes is analyzed in section 2.1. Design consideration of the proposed circuit is presented in section 3. Section 4 gives simulation and experimental results followed by comparison between proposed bidirectional converters and various conventional bidirectional converters with simulated output power and efficiency. Section 5 followed by the conclusions drawn from this investigation.

\section{Proposed circuit configuration}

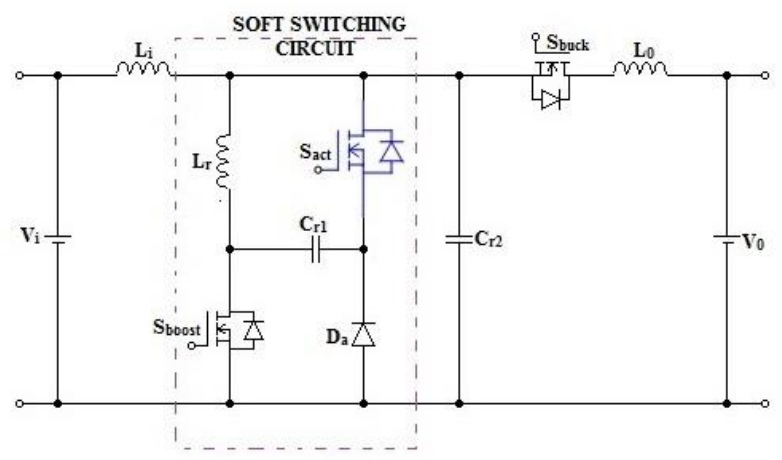

Fig. 1: Proposed Topology.

The proposed soft switching bi-directional dc-dc converter appears in Fig.1. Fig.1 comprises of three power semiconductor switches namely $S_{\text {boost }}, S_{\text {buck }}$, and $S_{\text {act. }}$. The switches $S_{\text {boost }}$ and $S_{\text {buck }}$ are operated only during the step up and step down conversion. Whereas, the switch $S_{\text {act }}$ works under all operating conditions. It consists of three inductors. Inductors $\mathrm{L}_{\mathrm{i}}$ and $\mathrm{L}_{0}$ are connected to input and output side voltages respectively for smoothing the current. Throughout the operation, the inductor current is continuous. The resonant inductor $\mathrm{Lr}_{\mathrm{r}}$, Resonant Capacitors $\mathrm{C}_{\mathrm{r}}$, brings on the resonance of the given circuit and $\mathrm{C}_{\mathrm{r} 2}$ and the Diode $\mathrm{D}_{\mathrm{a}}$ added with traditional bi-directional DC-DC converter topology.

The proposed setup is ordered into two types of conversion; boost mode conversion (step up) and buck mode conversion (step down).During step-up conversion, switches $S_{\text {boost }}$ and $S_{\text {act }}$ is operated to exchange power from $\mathrm{V}_{\mathrm{i}}$ to $\mathrm{V}_{0}$ through the intrinsic diode of $S_{\text {buck. }}$ On the other hand, a switch $S_{\text {buck }}$ and $S_{\text {act }}$ to the parallel diode of $\mathrm{S}_{\text {boost }}$ tends to work to exchange power from $\mathrm{V}_{0}$ to $\mathrm{V}_{\mathrm{i}}$. The proposed circuit minimizes the switching stresses and heat transfer issues of the traditional converter topologies.

\subsection{Operating principle}

One switching period of the proposed method has eight operating modes. The equivalent circuit and key waveforms explain them. Some assumptions are

- Power MOSFETs and diodes used in the bidirectional converter are assumed to be ideal and zero voltage drops.

- Throughout switching process reverse recovery of the converter, the diode is considered and taken into account.

- The output capacitor $\mathrm{C}_{0}$ is supposed to be large to produce a constant output voltage.

- The input inductor $\mathrm{L}_{\mathrm{i}}$ is considered as much more massive than snubber inductor $\mathrm{L}_{s}$ to have a constant input current.

\subsubsection{Boost mode}

In boost mode, main switch $S_{\text {boost }}$ and dynamic switch $S_{\text {act }}$ is controlled, and the anti-parallel diode of $S_{\text {buck }}$ operated to transfer power from $\mathrm{V}_{\mathrm{i}}$ to $\mathrm{V}_{0}$. The proposed bidirectional dc/dc converter has to boost the voltage of $80 \mathrm{~V}$ to that of the $160 \mathrm{~V}$ batteries. It is divided into eight operating modes. The operating mode of the proposed boost converter is explained below with its equivalent circuit. Fig. 10 represents the proposed boost converter key waveform.

Mode 1 [ $\mathrm{t}_{0} \leq \mathrm{t}<\mathrm{t}_{1}$ ] (Fig. 2): This mode starts with turning OFF switches $S_{\text {boost, }} S_{\text {buck, }}$ and $S_{\text {act. }}$ The input dc voltage $V_{i}$ is directly connected across the load through an input inductor current $i L_{i}$ and the body diode of a switch $S_{\text {buck. }}$. Here the voltage across $L_{i}$ is negative; therefore, inductor current i $L_{i}$ starts to decrease linearly.

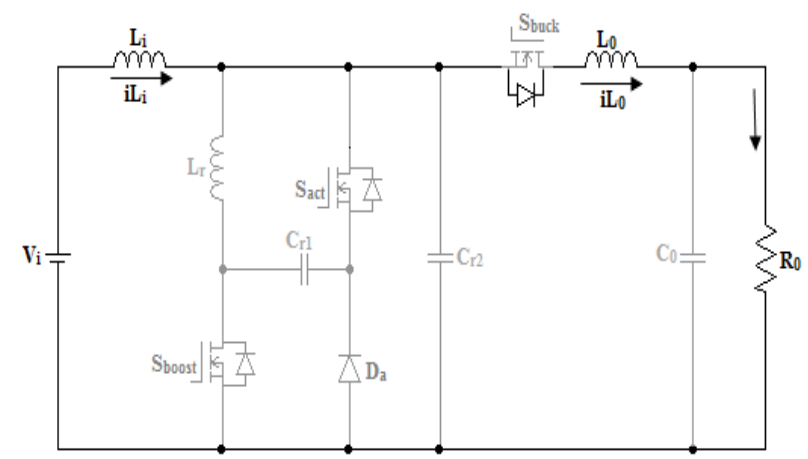

Fig. 2: Equivalent Circuit for Mode 1.

Mode 2 [t $1 \leq \mathrm{t}<\mathrm{t} 2]$ (Fig. 3): Mode 2 begins with turning ON of the switch $S_{\text {boost }}$ by ZCS because of $\mathrm{L}_{\mathrm{r}}$. The output voltage is supplied via the resonant inductor. Thus, $\mathrm{iL}_{\mathrm{r}}$ starts increasing. The current flowing through the intrinsic diode of the switch Sbuck becomes zero when $i \mathrm{~L}_{\mathrm{r}}=\mathrm{i} \mathrm{L}_{\mathrm{i}}$.

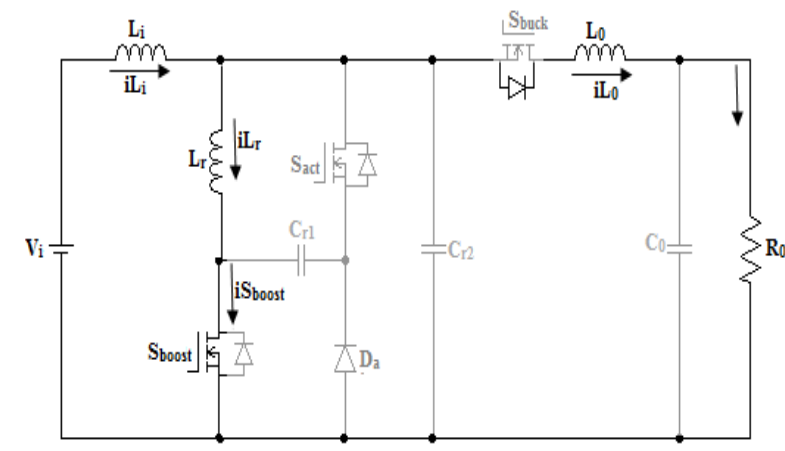

Fig. 3: Equivalent Circuit for Mode 2.

Mode 3 [ $\mathrm{t}_{2} \leq \mathrm{t}<\mathrm{t}_{3}$ ] (Fig. 4): At time $\mathrm{t}_{2}$ current through the body diode of the switch, $S_{\text {buck }}$ becomes zero. In this mode input induc- 
tor, current $i_{\mathrm{Li}}$ flows through $\mathrm{L}_{\mathrm{r}}$ and switches $\mathrm{S}_{\text {boost. The resonant }}$ inductor $\mathrm{L}_{\mathrm{r}}$ and the resonant capacitor $\mathrm{C}_{\mathrm{r} 2}$ start to resonate. Therefore, $\mathrm{V}_{\mathrm{Cr} 2}$ begins decreases from output voltage to zero.

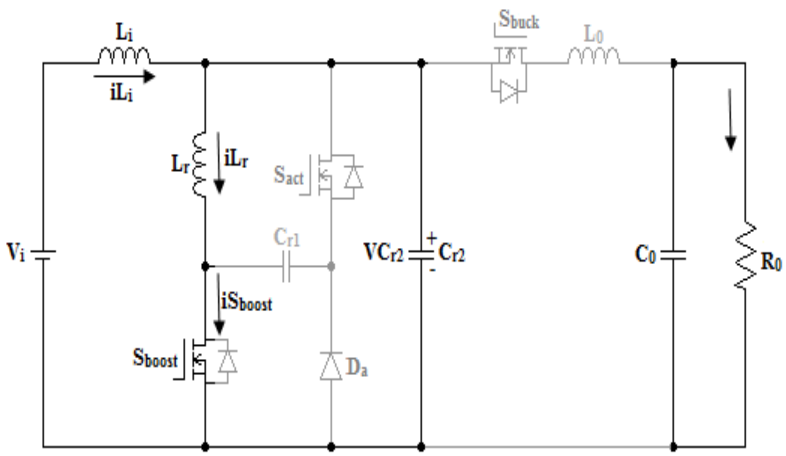

Fig. 4: Equivalent Circuit for Mode 3

Mode $4\left[\mathrm{t}_{3} \leq \mathrm{t}<\mathrm{t}_{4}\right.$ ] (Fig. 5): This mode begins at $\mathrm{VC}_{\mathrm{r} 2}=0$. Diode $\mathrm{D}_{\mathrm{a}}$ is conducting, and the switch $\mathrm{S}_{\text {act }}$ turns ON.

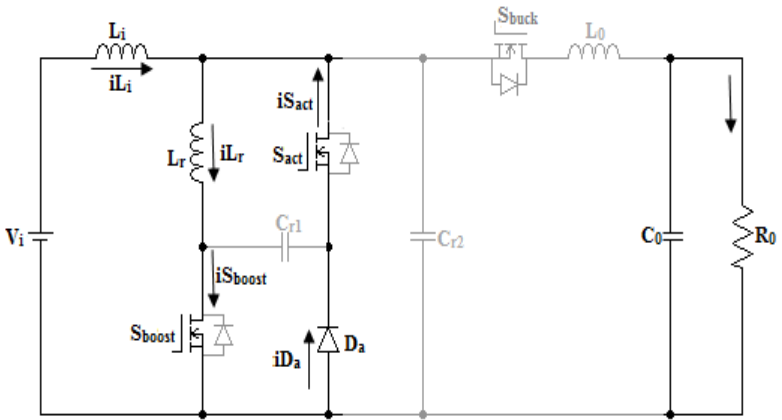

Fig. 5: Equivalent Circuit for Mode 4.

Mode 5 [t4 $\leq \mathrm{t}<\mathrm{t}_{5}$ ] (Fig. 6): At time $\mathrm{t}_{4}$, the switch $\mathrm{S}_{\text {boost }}$ is turned OFF with ZVS situation because of resonant capacitor $\mathrm{V}_{\mathrm{cr} 1}$ and switch $S_{\text {act }}$ remains $O N$. The proposed circuit serves two current loops in this mode.

i) $\mathrm{L}_{\mathrm{i}}-\mathrm{C}_{\mathrm{r} 2}-\mathrm{V}_{\mathrm{i}}, \mathrm{V}_{\mathrm{Cr} 2}$ increases from zero to output voltage

ii) $\mathrm{L}_{\mathrm{r}}-\mathrm{C}_{\mathrm{r} 1}-\mathrm{D}_{\mathrm{s}}$ act; loop for second resonance, energy captured in the $\mathrm{L}_{\mathrm{r}}$ shifts to $\mathrm{C}_{\mathrm{r} 1}$. Therefore, $\mathrm{iL}_{\mathrm{r}}$ starts decreasing and $\mathrm{VCr} 1$ becomes the high value.

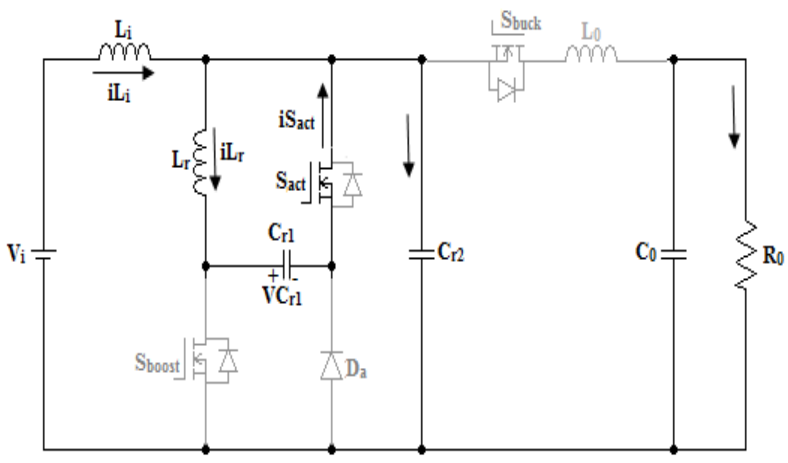

Fig. 6: Equivalent Circuit for Mode 5.

Mode $6\left[\mathrm{t}_{5} \leq \mathrm{t}<\mathrm{t}_{6}\right]$ (Fig. 7): This mode begins at $\mathrm{V}_{\mathrm{Cr} 1}=\mathrm{V}_{0}$ and $\mathrm{i} \mathrm{L}_{\mathrm{r}}=0$ because of energy stored in the resonant inductor is discharged to $\mathrm{V}_{\mathrm{Cr} 1}$. The switch $\mathrm{S}_{\text {act }}$ is turned OFF by ZVS.

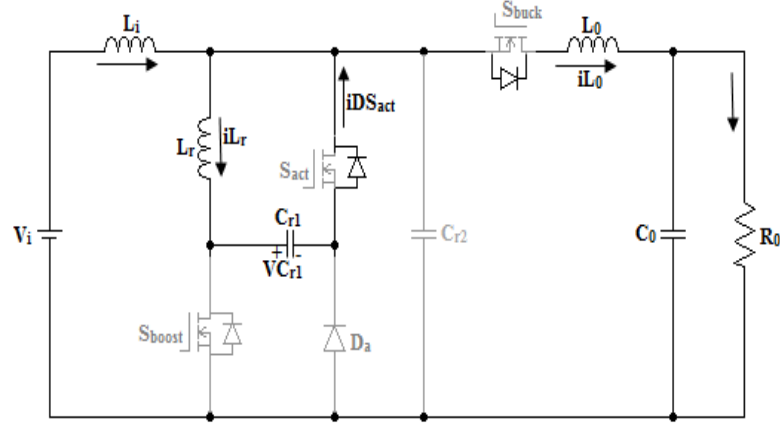

Fig. 7: Equivalent Circuit for Mode 6.

Mode 7 [ $\mathrm{t}_{6} \leq \mathrm{t}<\mathrm{t}_{7}$ ] (Fig. 8): In this mode $\mathrm{V}_{\mathrm{Cr} 1}$ starts to resonate and decreases through $\mathrm{D}_{2}-\mathrm{C}_{\mathrm{r} 1}-\mathrm{L}_{\mathrm{r}}-\mathrm{D}_{\mathrm{s} 2}-\mathrm{C}_{0}$ until $\mathrm{V}_{\mathrm{Cr} 1}=0$, the energy absorbed in $\mathrm{Cr} 1$ discharges to resonant inductor $\mathrm{L}_{\mathrm{r}}$. At the point $\mathrm{VC}_{\mathrm{r} 1}=0, \mathrm{iL}_{\mathrm{r}}$ alters its current direction, the body diode of a switch, Sbuck begins conducting.

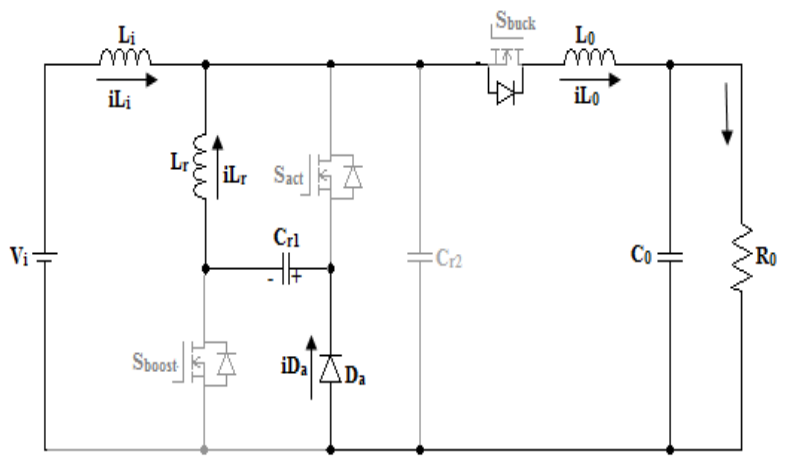

Fig. 8: Equivalent Circuit for Mode 7.

Mode 8 [ $\mathrm{t}_{7} \leq \mathrm{t}<\mathrm{t}_{8}$ ] (Fig. 9): This mode begins at $\mathrm{VC}_{\mathrm{r} 1}=0$. It has two current paths. The main inductor current $i L_{i}$ flows to the load via intrinsic diode of the switch $S_{\text {buck }}$ at the point resonant inductor current shifts to the load through Dsboost and Dsbuck. This mode ends at $i L_{r}$ reaches to zero.

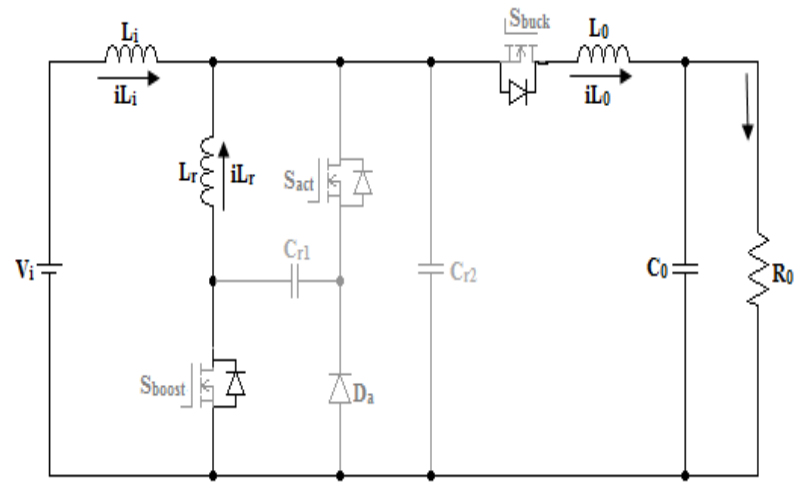

Fig. 9: Equivalent Circuit for Mode 8 


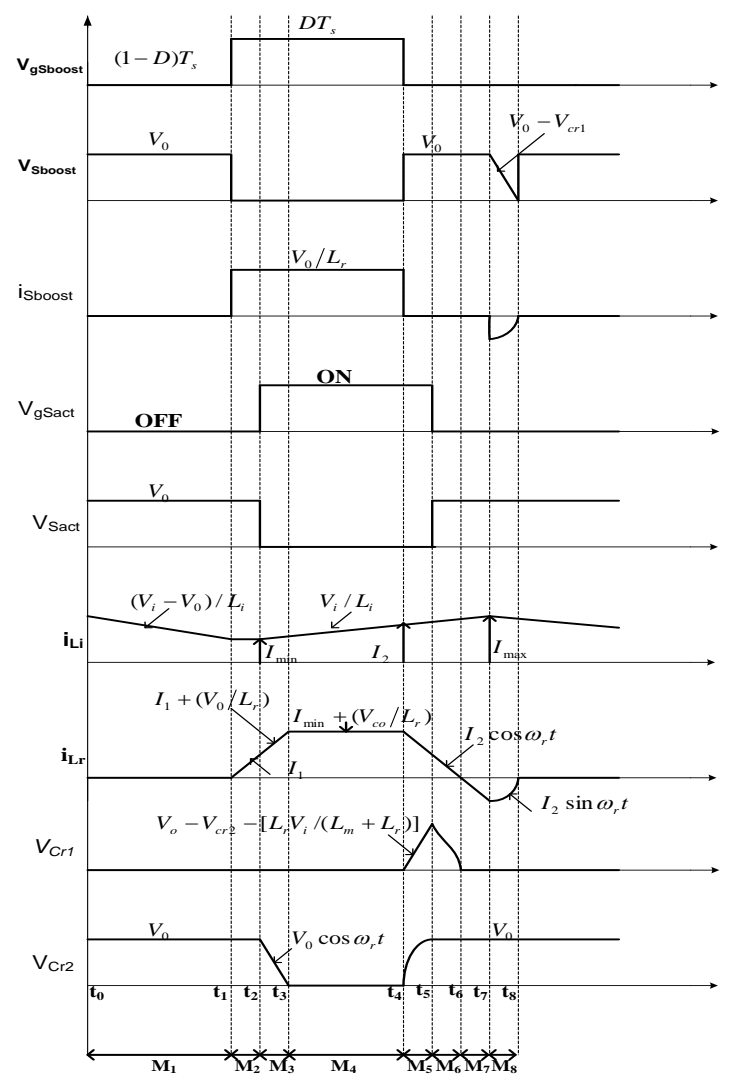

Fig. 10: The Key Waveforms of the Proposed Boost Converter.

\subsubsection{Buck mode}

In buck mode, main switch $S_{\text {buck }}$ and active switch $S_{\text {act }}$ is controlled, and the anti-parallel diode of $S_{\text {boost }}$ operated to transfer power from high-voltage input side to the low voltage output side. The proposed bidirectional dc/dc converter has to step down the voltage of $160 \mathrm{~V}$ to that of the $80 \mathrm{~V}$ battery bank. It is divided into eight operating modes. Each operating mode of the proposed buck converter is explained below with its equivalent circuit. Fig. 19 represents the proposed buck converter key waveform.

Mode $1\left[\mathrm{t}_{0} \leq \mathrm{t}<\mathrm{t}_{1}\right]$ (Fig. 11): This mode starts with turning off switches $S_{\text {boost }}, S_{\text {buck, }}$, and $S_{\text {act. }}$. The input dc voltage $V_{0}$ directly connected across the load through an inductor current iLo. Here the voltage across $\mathrm{L}_{0}$ is negative. Therefore, inductor current $i \mathrm{~L}_{\circ}$ starts to decreases linearly.

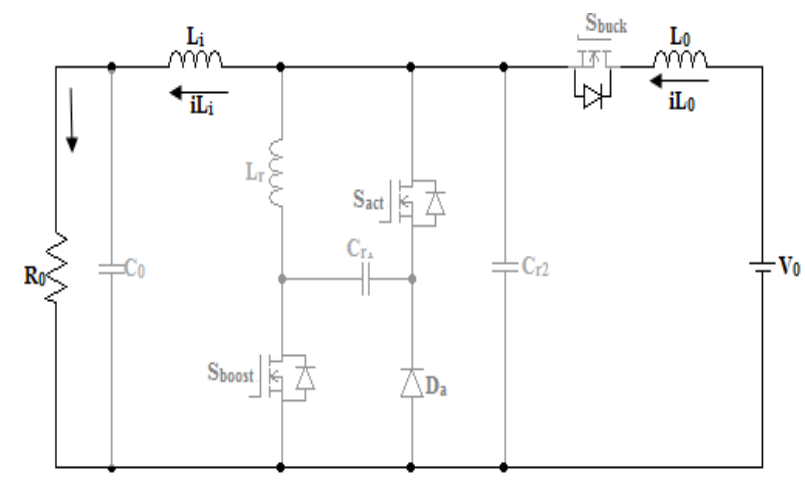

Fig. 11: Equivalent Circuit for Buck-Mode 1.

Mode 2 [ $\mathrm{t} 1 \leq \mathrm{t}<\mathrm{t} 2$ ] (Fig. 12): Mode 1 begins with turning ON of a switch $S_{\text {buck }}$ by ZCS because of $\mathrm{L}_{r}$. The output voltage is supplied via the resonant inductor. Thus, $\mathrm{iL}_{\mathrm{r}}$ starts increasing its reverse direction. The current complete the body diode of the switch $S_{\text {boost }}$ becomes zero when $\mathrm{iL}_{\mathrm{r}}=\mathrm{i} \mathrm{L}_{0}$

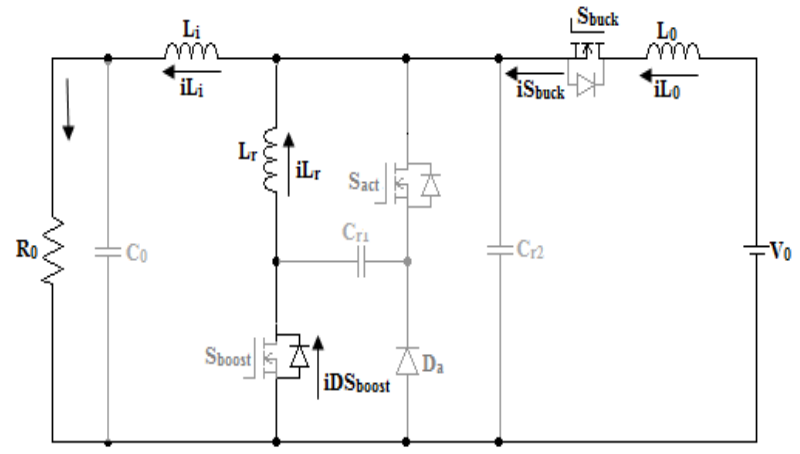

Fig. 12: Equivalent Circuit for Buck-Mode 2.

Mode $3\left[\mathrm{t}_{2} \leq \mathrm{t}<\mathrm{t}_{3}\right.$ ] (Fig. 13): At time $\mathrm{t}_{2}$ current through the intrinsic diode of a switch, $\mathrm{S}_{\text {boost }}$ becomes zero. The resonant capacitor $\mathrm{C}_{\mathrm{r} 2}$ starts to resonate. Therefore, $\mathrm{VC}_{\mathrm{r} 2}$ begins decreases from output voltage to zero.

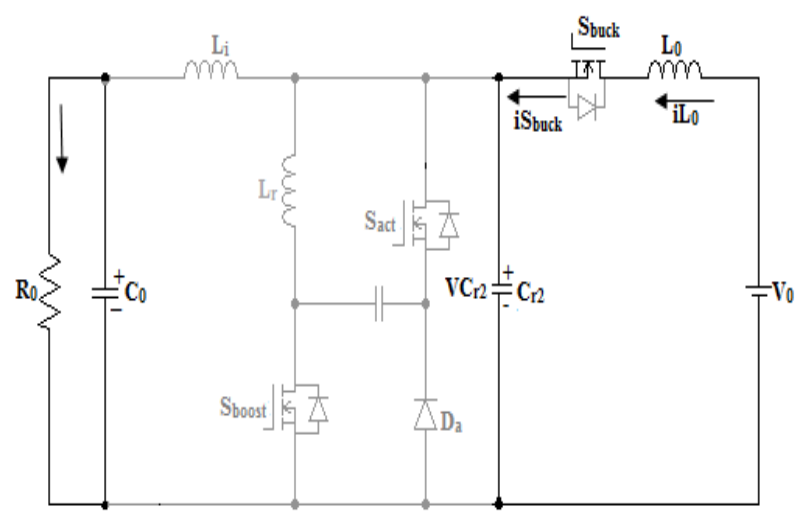

Fig. 13: Equivalent Circuit for Buck-Mode 3.

Mode $4\left[\mathrm{t}_{3} \leq \mathrm{t}<\mathrm{t}_{4}\right]$ (Fig. 14): This mode begins at $\mathrm{VC}_{\mathrm{r} 2}=0$. Diode $\mathrm{D}_{\mathrm{a}}$ is conducting, and the switch $\mathrm{S}_{\text {act }}$ turns $\mathrm{ON}$.

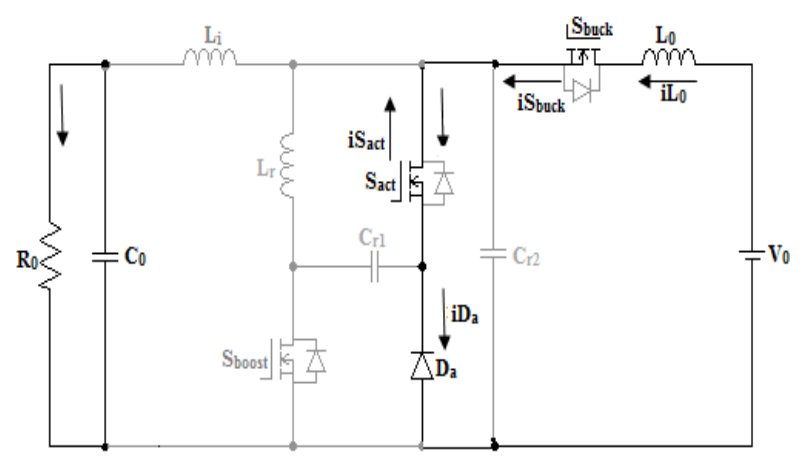

Fig. 14: Equivalent Circuit for Buck-Mode 4.

Mode 5 [ $\mathrm{t}_{4} \leq \mathrm{t}<\mathrm{t}_{5}$ ] (Fig. 15): In this mode, the switch $\mathrm{S}_{\text {buck }}$ is turned OFF with ZVS condition because of resonant capacitor $\mathrm{V}_{\mathrm{cr} 2}$.

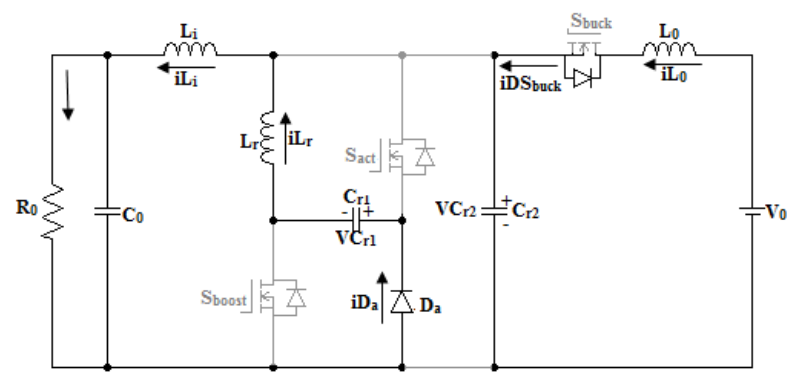

Fig. 15: Equivalent Circuit for Buck-Mode 5.

Mode 6 [ $\mathrm{t}_{5} \leq \mathrm{t}<\mathrm{t}_{6}$ ] (Fig. 16): This mode begins at $\mathrm{VC}_{\mathrm{r} 1}=\mathrm{V}_{0}$ and $\mathrm{iL}_{\mathrm{r}}$ $=0$ because of energy stored in the resonant inductor is entirely 
discharged to $\mathrm{VC}_{\mathrm{r} 1}$. The proposed circuit serves two current loops in this mode.

i) $\mathrm{L}_{0}-\mathrm{C}_{0}-\mathrm{V}_{\mathrm{o}}, \mathrm{VC}_{\mathrm{r} 2}$ increases from zero to output voltage.

ii) $\mathrm{L}_{\mathrm{r}}-\mathrm{C}_{\mathrm{r} 1}-\mathrm{Ds}$ act, loop for second resonance, the energy stored in the resonant inductor shifts to $\mathrm{C}_{\mathrm{r} 1}$. Therefore, $\mathrm{i} \mathrm{L}_{\mathrm{r}}$ starts decreasing and $\mathrm{V}_{\mathrm{Cr} 1}$ becomes a high value.

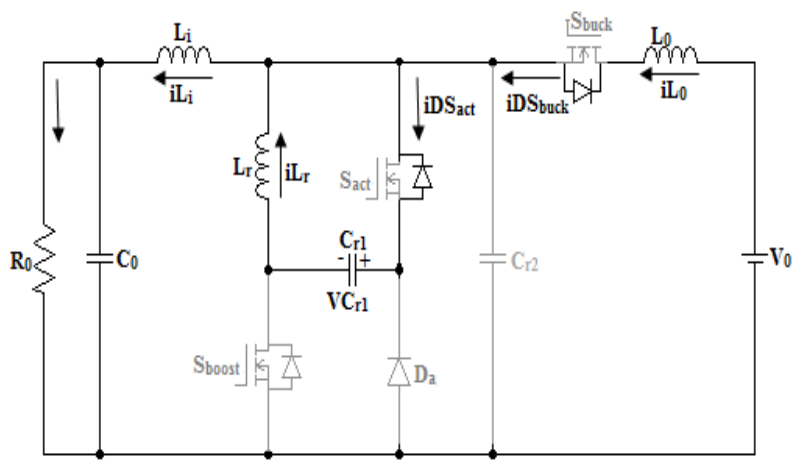

Fig. 16: Equivalent Circuit for Buck-Mode 6.

Mode 7 [ $\mathrm{t}_{6} \leq \mathrm{t}<\mathrm{t}_{7}$ ] (Fig. 17): At time $\mathrm{t}_{6}, \mathrm{VC}_{\mathrm{r} 1}$ starts to resonate and decreases through $\mathrm{D}_{2}-\mathrm{C}_{\mathrm{r} 1}-\mathrm{Lr}_{-}-\mathrm{Li}_{\mathrm{i}}-\mathrm{C}_{0}$ until $\mathrm{V}_{\mathrm{Cr} 1}=0$.the energy absorbed in $\mathrm{C}_{\mathrm{r} 1}$ discharges to resonant inductor $\mathrm{L}_{\mathrm{r}}$. $\mathrm{VC}_{\mathrm{r} 1}=0$, $\mathrm{iL}_{\mathrm{r}}$ changes its current direction.

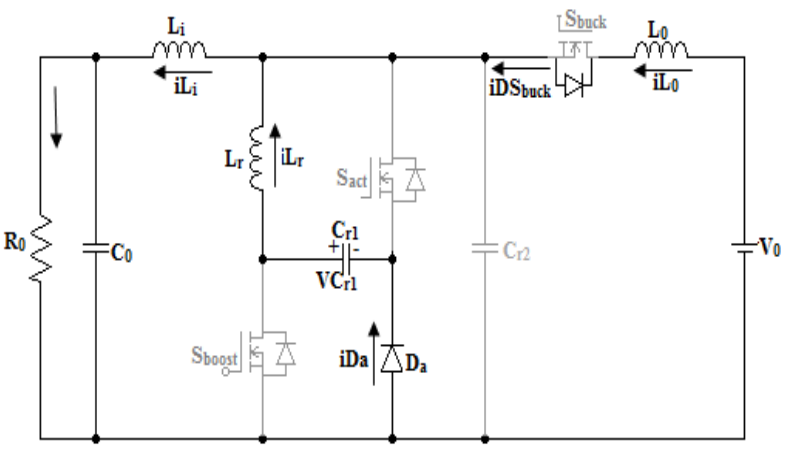

Fig. 17: Equivalent Circuit for Buck-Mode 7.

Mode 8 [ $\mathrm{t}_{7} \leq \mathrm{t}<\mathrm{t}_{8}$ ] (Fig. 18): This mode begins at $\mathrm{VC}_{\mathrm{r} 1}=0$. It has two current paths. The output inductor current flows to the load via intrinsic diode of the switch $S_{\text {boost }}$ and resonant inductor current shifts to the heap through Dsboost and Dsbuck. This mode ends at $i L_{r}$ reaches to zero.

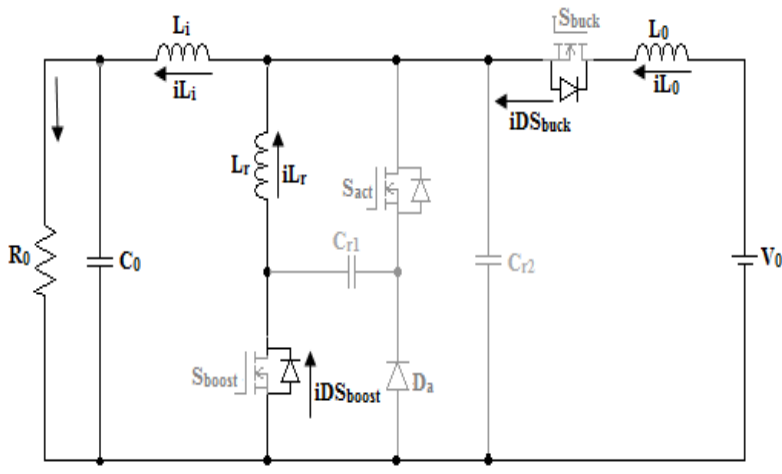

Fig. 18: Equivalent Circuit for Buck-Mode 8.

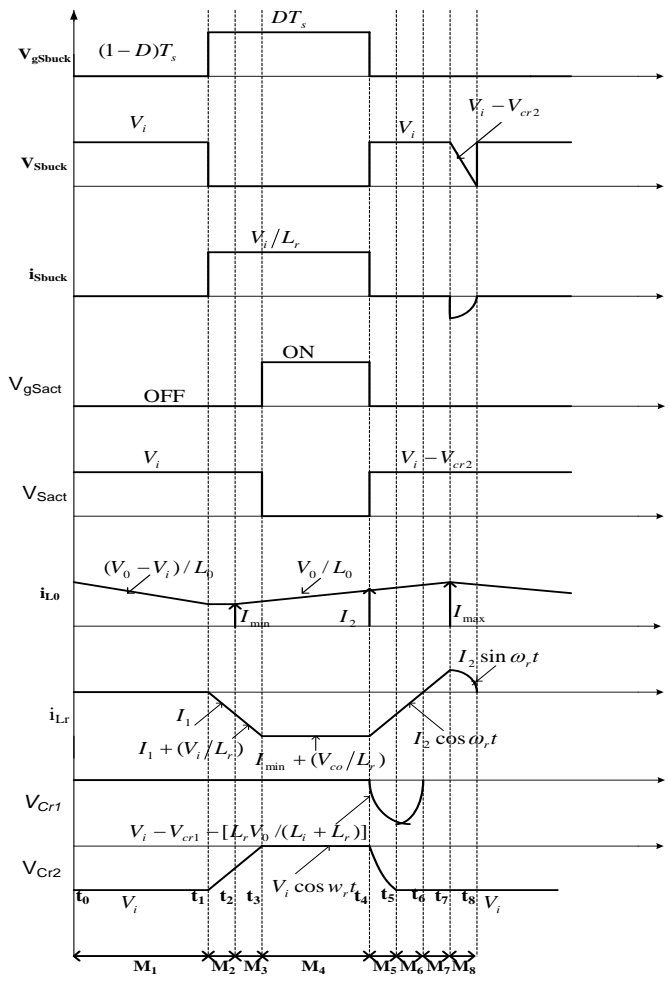

Fig. 19: The Key Waveforms of the Proposed Buck Converter.

\section{Design of proposed topology}

\subsection{Input inductor $\mathrm{Li}$}

The input side inductor $\mathrm{L}_{\mathrm{i}}$ ought to be calculated in such a way that the current moves through it should be less than the current that it can withstand, i.e., two times the maximum input current:

$L_{i}=\frac{V_{i} * T_{s} * D}{2 * \Delta I L_{i}}$

\subsection{Resonant inductor $\mathrm{Lr}$}

For achieving ZCS turns ON of the switches. The required value of the resonant inductor is determined from the following equation:

$$
L_{r}>L_{r},_{\min }=\frac{\left(V_{0}-V_{c r 1}\right) t_{r}}{I_{i}}
$$

Where tr is the ascent time of the switch current.

When the switch Sboost is turned $\mathrm{ON}$ at $\mathrm{t}=\mathrm{t} 2$, the reverse recovery current of the active diode $\mathrm{Da}$ flows through the resonant inductor. $^{\left(V_{0}-V_{c r 2}\right)}$ Is the voltage to be incorporated by resonant inductor Lr to avail the zero current switching condition to turn ON the switch Sboost. When $\mathrm{Lr}$ increases, it will decrease the turn ON losses of the switch. The maximum inductance value of $\mathrm{Lr}$ is given as

$$
L_{r}>L_{r},_{\max }=\frac{V_{c r 1} T_{s}(1-D)}{I L_{r}\left(t_{2}\right)}
$$

\subsection{Resonant capacitors $\mathrm{Cr} 1$ and $\mathrm{Cr} 2$}

To control the dv/dt of the switch at turn OFF resonant capacitor $\mathrm{Cr} 1$ is connected in between Sboost and Sact. The minimum value of $\mathrm{Cr} 1$ depends upon the output voltage, as it will appear across Cr1 during the switch Sboost turns OFF. 


$$
C_{r 1}>C_{r 1} \eta_{\min }=\frac{I S_{\text {boost }}\left(t_{2}\right) * t_{f}}{2 V_{0}}
$$

Where, $\mathrm{tf}$ is the fall time of the switch current.

When Cr1increases the turn-off losses of the switch decreased since the voltage across the switch drops.

For ZVS turn OFF: Vcr1 (t2) $=0$

From this maximum value of $\mathrm{Cr} 1$ is expressed as:

$$
C_{r 1}>C_{r 1},_{\max }=\frac{1}{L_{r}}\left[\frac{t_{2}-t_{1}}{\cos ^{-1}\left(-V_{c r 2}\left(V_{0}-V_{c r 2}\right)\right)}\right]^{2}
$$

The value of resonant capacitor $\mathrm{Cr} 2$ can be determined by.

$$
C_{r 2}=\frac{1}{4 \Pi^{2} f^{2} L_{r}}
$$

\subsection{Input and output capacitor}

During boost and buck mode conversion, the input and output capacitor must be connected across applied dc input voltage and the load. The value of such a capacitor can be evaluated from.

$$
\begin{gathered}
C_{i}=\frac{V_{i} * T_{s} * D}{R_{0} * \Delta V C_{i}} \\
C_{0}=\frac{V_{0} * T_{s} * D}{2 * \Delta V C_{0}}
\end{gathered}
$$

\section{Results and discussions}

The overall concert of the proposed bidirectional converter circuit is predictable with the prototype developed according to Fig. 20.

\begin{tabular}{|c|c|}
\hline Components & Value \\
\hline Input Voltage $\mathrm{V}_{\mathrm{i}}$ & $80 \mathrm{~V}$ \\
\hline Output VoltageV $_{0}$ & $160 \mathrm{~V}$ \\
\hline Maximum Output Power $\mathrm{P}_{0}$ & $0.35 \mathrm{KW}$ \\
\hline Input Inductor $\mathrm{L}_{\mathrm{i}}$ & $450 \mu \mathrm{H}$ \\
\hline Resonant Inductor $\mathrm{L}_{\mathrm{r}}$ & $4 \mu \mathrm{H}$ \\
\hline Resonant Capacitor $\mathrm{C}_{\mathrm{r} 1}$ & $18 \mathrm{nF}$ \\
\hline Resonant Capacitor $\mathrm{C}_{\mathrm{r} 2}$ & $80 \mathrm{nF}$ \\
\hline Output Capacitor $\mathrm{C}_{0}$ & $47 \mu \mathrm{F}$ \\
\hline$S_{\text {boost }}, S_{\text {buck }}$ and $S_{\text {act }}$ & IRF840 \\
\hline Diode $\mathrm{D}_{\mathrm{a}}$ & IN4007 \\
\hline Switching Frequency & $20 \mathrm{KHZ}$ \\
\hline
\end{tabular}
The parameters of LCD snubber circuit components are resolute using Equations (1)-(8). The components used in the experimental set-up of the proposed converter are summarized in Table 1.

Table 1: Utilized Simulation and Experimental Parameters

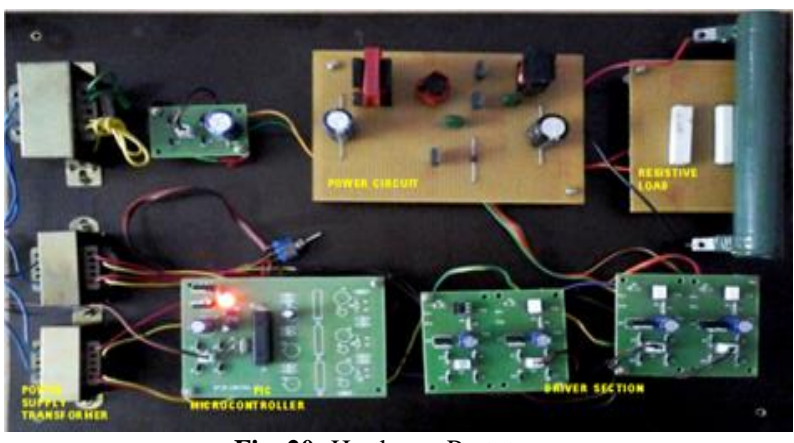

Fig. 20: Hardware Prototype.

The proposed converter is working with an input voltage of $\mathrm{V}_{\mathrm{i}}=$ $80 \mathrm{~V}$, which is stepped up to the output dc voltage of $\mathrm{V}_{0}=160 \mathrm{~V}$ for the step up-conversion and $\mathrm{P}_{0}=315 \mathrm{~W}$ at $\mathrm{f}_{\mathrm{s}}=20 \mathrm{kHz}$. The output voltage got is double time greater than that of input voltage given. The measured efficiency is about $94.5 \%$, for boost conversion, which is evident from the measured input/output voltage and current waveforms as shown in the below figures. Simulated results are placed on the left-hand side, and experimental results are located on the right-hand side.

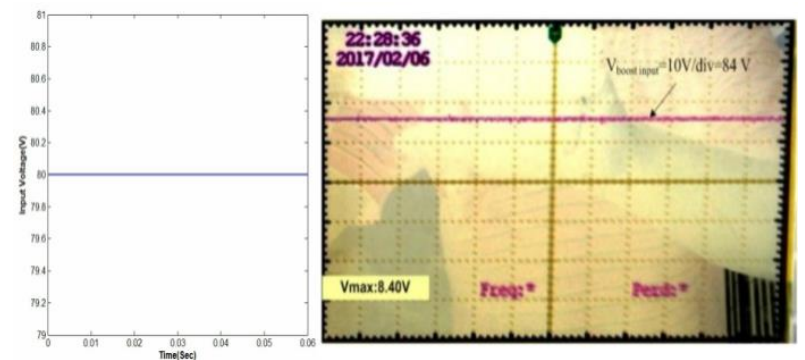

Fig. 21: Simulated and Experimental Waveforms of Input Voltage-Boost Mode.

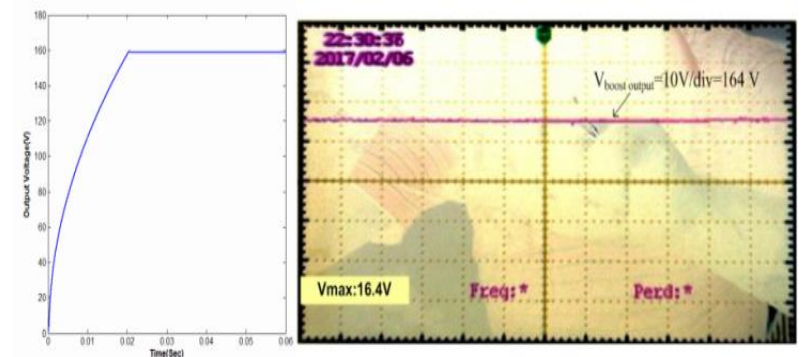

Fig. 22: Simulated and Experimental Waveforms of Output Voltage-Boost Mode.

Fig. 21 shows the simulated and experimental waveforms of boost mode dc input voltages $80 \mathrm{~V}$ and $80.4 \mathrm{~V}$ respectively. During step-up transformation, the output voltage got is two times than greater than input given. It is evident to the fig. 22. It shows the measured output voltage of $160 \mathrm{~V}$, which is twice than the input.

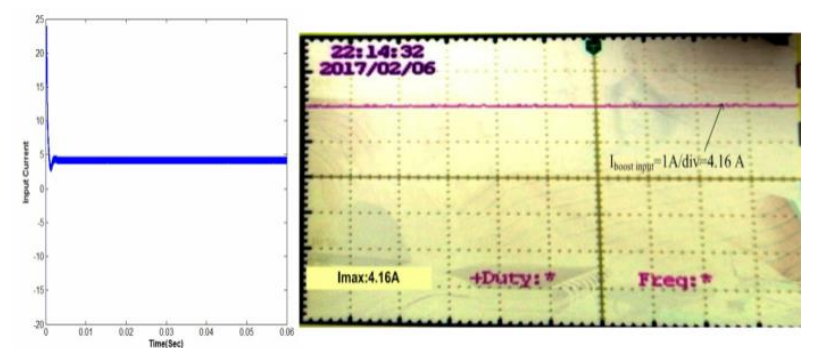

Fig. 23: Simulated and Experimental Waveforms of Input Current-Boost Mode.

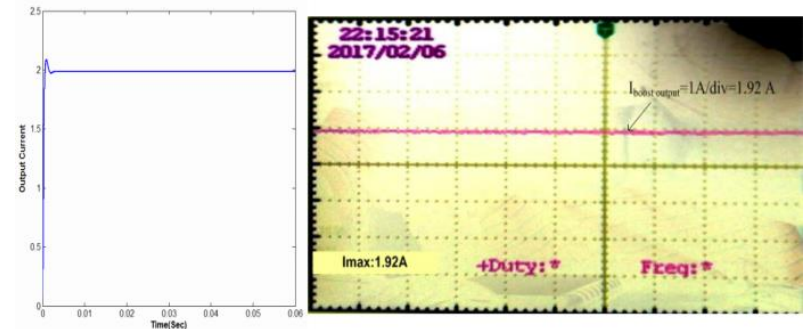

Fig. 24: Simulated and Experimental Waveforms of Output Current-Boost Mode.

The simulated and experimental waveforms for the proposed boost mode input and output current are obtained in fig. 23 and fig. 24. From the above input/output current and voltage results, we can compute the efficiency of the proposed boost converter, and 94.5 $\%$ are evaluated for boost mode. The same can be applied to the wide range of input voltages. 


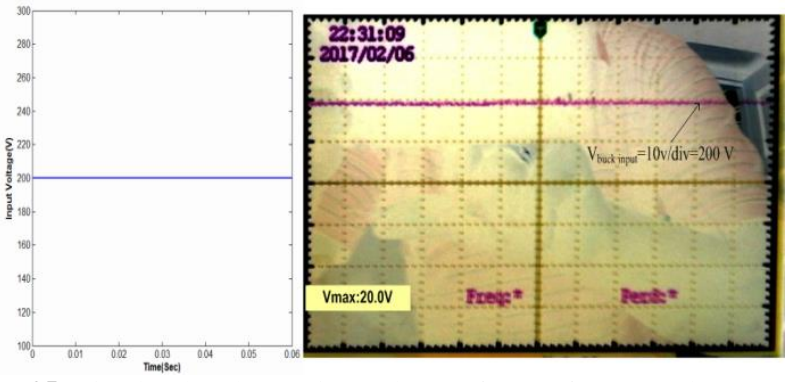

Fig. 25: Simulated and Experimental Waveforms of Input Voltage-Buck Mode.

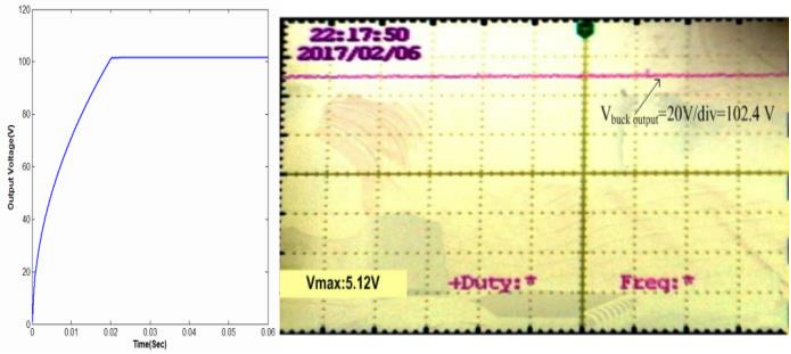

Fig. 26: Simulated and Experimental Waveforms of Output Voltage-Buck Mode.

On the other hand, Fig. 25 reveals the simulated and experimental buck mode dc input voltage of $200 \mathrm{~V}$. During buck mode, conversion the output obtained is half than given input voltage. It is reversing than the boost mode conversion. This is noticed in Fig. 26. In fig.26, the simulated and experimental output voltages show nearly 100 and $102.4 \mathrm{~V}$, which is half than the input voltage given.

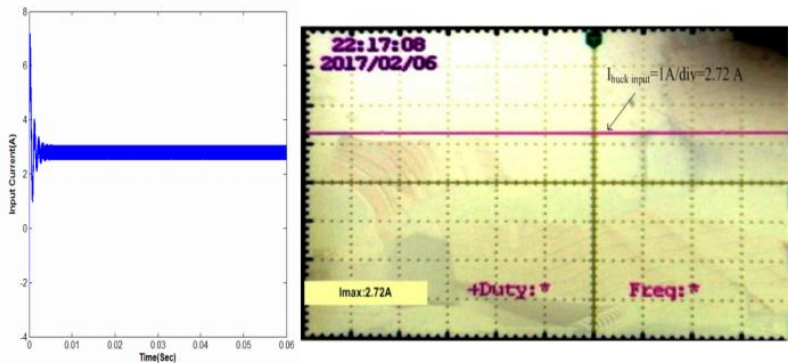

Fig. 27: Simulated and Experimental Waveforms of Input Current-Buck Mode.

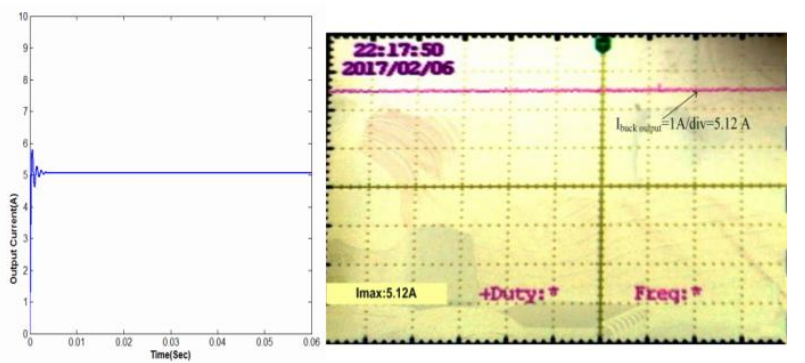

Fig. 28: Simulated and Experimental Waveforms of Output Current-Buck Mode.

The simulated and experimental waveforms for the proposed buck mode input and output current are obtained in fig. 27 and fig. 28. From the above input/output current and voltage waveforms, we can compute the efficiency of the proposed buck converter and reach up to $93 \%$ for buck mode. The same can be applied to the full range of various input voltages.
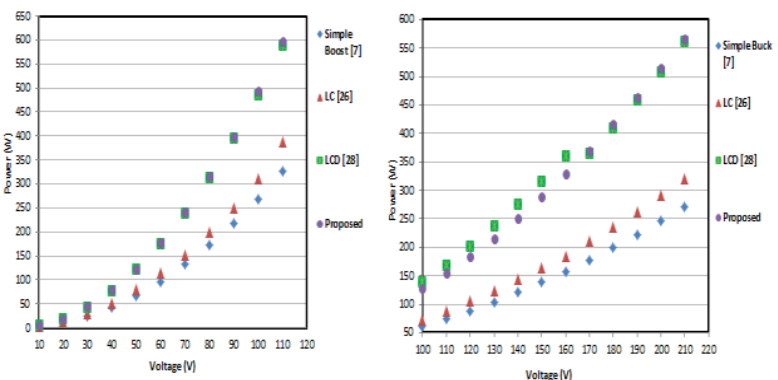

Fig. 29: Output Power under Different Input Voltages-Boost and Buck Mode.
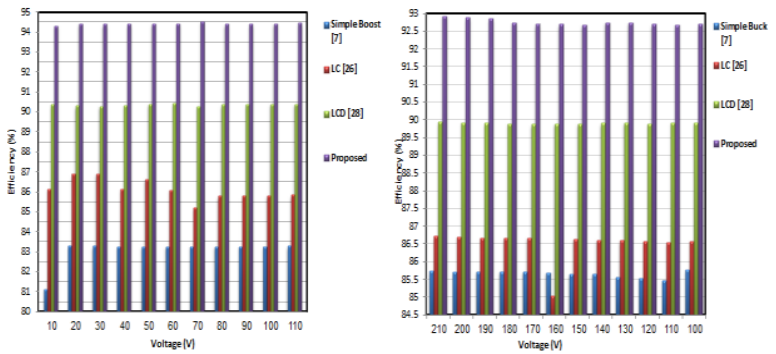

Fig. 30: Efficiency under Different Input Voltages-Boost and Buck Mode.

Table 2: The Overall Performance of the Proposed Bidirectional DC-DC Converter and Conventional Bi-Directional DC-DC Converter

\begin{tabular}{|c|c|c|c|c|}
\hline Circuit Topology & $\begin{array}{l}\text { Components } \\
\text { Counts }\end{array}$ & $\begin{array}{l}\text { Switching } \\
\text { features }\end{array}$ & $\begin{array}{l}\text { Efficiency } \\
\text { Buck } \\
\text { mode }\end{array}$ & $\begin{array}{l}\text { Boost } \\
\text { Mode }\end{array}$ \\
\hline $\begin{array}{l}\text { Bidirectional dc-dc } \\
\text { converter with } \\
\text { auxiliary switch } \\
\text { control [7] }\end{array}$ & $\begin{array}{l}4 \text { switches } \\
4 \text { Capacitors } \\
2 \text { Inductors }\end{array}$ & $\begin{array}{l}\text { Switch - } \\
\text { ZVS turn } \\
\text { ON } \\
\text { and ZCS } \\
\text { turn OFF }\end{array}$ & $85.70 \%$ & $83.20 \%$ \\
\hline $\begin{array}{l}\text { Bidirectional dc-dc } \\
\text { converter with LC } \\
\text { Resonant Circuit } \\
{[26]}\end{array}$ & $\begin{array}{l}\text { No Diodes } \\
2 \text { switches } \\
3 \text { Capacitors } \\
2 \text { Inductors } \\
\text { No Diodes }\end{array}$ & $\begin{array}{l}\text { Switch - } \\
\text { ZVS turn } \\
\text { ON } \\
\text { and ZVS } \\
\text { turn OFF }\end{array}$ & $86.60 \%$ & $86.90 \%$ \\
\hline $\begin{array}{l}\text { Bidirectional dc-dc } \\
\text { converter with LCD } \\
\text { clamp circuit [28] }\end{array}$ & $\begin{array}{l}2 \text { switches } \\
2 \text { Capacitors } \\
3 \text { Inductors } \\
2 \text { Diodes }\end{array}$ & $\begin{array}{l}\text { Switch - } \\
\text { ZCS turn } \\
\text { ON } \\
\text { and ZVS } \\
\text { turn OFF }\end{array}$ & $89.94 \%$ & $90.30 \%$ \\
\hline $\begin{array}{l}\text { Proposed bidirec- } \\
\text { tional dc-dc con- } \\
\text { verter with dynamic } \\
\text { switch (Proposed) }\end{array}$ & $\begin{array}{l}3 \text { switches } \\
2 \text { Capacitors } \\
3 \text { Inductors } \\
1 \text { Diode }\end{array}$ & $\begin{array}{l}\text { Switch- } \\
\text { ZCS turn } \\
\text { ON } \\
\text { and ZVS } \\
\text { turn OFF }\end{array}$ & $92.90 \%$ & $94.40 \%$ \\
\hline
\end{tabular}

The Figures 29 and 30 have plotted with the help of simulation work carried out in the MATLAB software for the proposed circuit topology. It has done to verify the effectiveness of the current circuit regarding efficiency and output power for changes with the input voltage. Based on the simulation results obtained the output power and efficiency of the proposed soft switching-directional dc-dc converter is compared with three other non-isolated bidirectional dc-dc converters with same input voltages. Conventional topologies such as the traditional bidirectional converter, LC resonant comprises of simple passive components and a simple nondissipative LCD snubber.

From the above discussion, it is very clearly observed in table 2 . That the proposed non-isolated bidirectional dc-dc converter with soft switching achieves high efficiency over the full range of input and load ranges than the conventional circuit topologies. 


\section{Conclusion}

In this paper, a soft switching bi-directional buck-boost converter with a high conversion ratio is proposed. This proposed technique is suitable to achieve high efficiency and maximum power conversion at all operating principles. The steady-state analysis of the proposed soft switching bi-directional converter is carried out at all working stages of boost and buck mode conversion. A nondissipative lossless soft switching circuit is presented to overpower the switching losses appeared across the power semiconductor switches and maximize the converter efficiency up to $94.5 \%$ and $93 \%$ for the step up and step down conversion. The entire converters switch operated at ZVS, and ZCS conditions are described. The proposed topology is confirmed through simulation and experimental results. From these results, the proposed bidirectional converter accomplishes high efficiency than the traditional bidirectional converter.

\section{References}

[1] Do HL (2013), Analysis and implementation of a high-efficiency zero-voltage-zero current switching dc-dc converter. International Journal of Circuit Theory and Applications, 41, 889-903. https://doi.org/10.1002/cta.827.

[2] Choi BH, Lee ES, Kim JH \& Rim CT (2015), DCM analysis of single-switch-based zvzcs converters with a tapped inductor. IEEE Transactions on Power Electronics, 30, 6617-6627. https://doi.org/10.1109/TPEL.2015.2393362.

[3] Yang JW, \& Do HK (2014), A soft-switching high step-up dc-dc converter with a single magnetic component. International Journal of Circuit Theory and Applications, 42, 620-631. https://doi.org/10.1002/cta.1876.

[4] Liu HC, \& Li F (2015), Novel high step-up dc-dc converter with an active coupled-inductor network for a sustainable energy system. IEEE Transactions on Power Electronics, 30, 6476-6482. https://doi.org/10.1109/TPEL.2015.2429651.

[5] kazimierczuk M.K (2008), Pulse-width modulated dc-dc power converters. John Wiley \& Sons, Ltd, 2008.

[6] Samosir AS \& Yatim AHM (2010), Dynamic evolution control for synchronous buck dc-dc converter: Theory, model and simulation. Simulation Modelling Practice and Theory, 18, 663-676. https://doi.org/10.1016/j.simpat.2010.01.010.

[7] Lee JH, Yu D-H, Kim J-G, Kim Y-H, Shin S-C, Jung D-Y, Jung Y C \& Won C-Y (2013), Auxiliary Switch Control of a Bidirectional Soft-Switching DC/DC Converter, IEEE Transactions on Power Electronics. 28 , https://doi.org/10.1109/TPEL.2013.2254131.

[8] Hwu KI \& Jiang WZ (2016), Non-isolated large step-down voltage conversion ratio converter with non-pulsating output current. International Journal of Circuit Theory and Applications, 44, 1657-1684. https://doi.org/10.1002/cta.2185.

[9] Bella TL, Yu W, Lai J-S (J). Senesky M, \& Anderson D (2014), A bidirectional-switch-based wide-input range high-efficiency isolated resonant converter for photovoltaic applications. IEEE Transactions on Power Electronics. 29, 3473-3484 https://doi.org/10.1109/TPEL.2013.2282258.

[10] Banu JB \& Moses MB (2016), Soft-switching bidirectional buck boost converter with simple auxiliary circuit. Indian Journal of Science and Technology, 9, 1-10.

[11] Xuewei P \& Rathore AK (2013), Novel interleaved bidirectiona snubberless soft-switching current-fed full-bridge voltage doubler for fuel-cell vehicles. IEEE Transactions on Power Electronics, 28, 5535-5546. https://doi.org/10.1109/TPEL.2013.2252199.

[12] Yao C, Ruan X, Wang X \& Tse CK (2011), Isolated buck-boost $\mathrm{dc} / \mathrm{dc}$ converters suitable for wide input-voltage range. IEEE Transactions on Power Electronics, 26, 2599-2613. https://doi.org/10.1109/TPEL.2011.2112672.

[13] Lin C-C, Yang L-S, \& Wu GW (2013), Study of a non-isolated bidirectional dc-dc converter. IET Power Electronics. 6, 30-37. https://doi.org/10.1049/iet-pel.2012.0338.

[14] Bhajana VVK, \& Drabek P (2015), A new non-isolated zcs bidirectional buck-boost dc-dc converter for energy storage applications in electric vehicles. Arabian Journal of Science and Engineering, 40, 3595-3605. https://doi.org/10.1007/s13369-015-1840-5.

[15] Chiu H-J, Lo Y-K, Kuo S-W, Cheng S-J \& Lin F-T (2014), Design and implementation of a high-efficiency bidirectional dc-dc con- verter for dc micro-grid system applications. International Journal of Circuit Theory and Applications, 42, 1139-1153. https://doi.org/10.1002/cta.1910.

[16] Lee J-H, Yu D-H, Kim J-G, Kim, Y-H, Shin S-C, Jung D-Y, Jung Y-C, \& Won C-Y (2013), Auxiliary switch control of a bidirectional soft-switching $\mathrm{dc} / \mathrm{dc}$ converter.IEEE Transactions on Power Electronics, 28 https://doi.org/10.1109/TPEL.2013.2254131.

[17] Ling R, Zhao G \& Huang Q (2015), High step-up interleaved boost converter with low switch voltage stress. Electric Power Systems Research, 128, 11-18. https://doi.org/10.1016/j.epsr.2015.06.016.

[18] Lin BR \& Chao CH (2013), Analysis and implementation of an interleaved zvs converter with high input voltage. International Journal of Circuit Theory and Applications. 41, 924-945. https://doi.org/10.1002/cta.830.

[19] Samavatian V \& Radan A (2015), A high efficiency input/output magnetically coupled interleaved buck-boost converter with low internal oscillation for fuel-cell applications: Small signal modeling and dynamic analysis. Electrical Power and Energy Systems, 67, 261-271. https://doi.org/10.1016/j.ijepes.2014.11.011.

[20] Aroudi AE, Mandal K, Giaouris D, Banerjee S, Abusorrah A, Hindawi MA, \& Al-Turki Y (2015), Fast-scale stability limits of a two-stage boost power converter. International Journal of Circuit Theory and Applications, 44, 1127-1141. https://doi.org/10.1002/cta.2153.

[21] Liu C, Zhu D, Zhang J, Liu H \& Cai G (2015), A bidirectional dual buck-boost voltage balancer with direct coupling based on a burstmode control scheme for low-voltage bipolar-type de microgrids. Journal of Power Electronics, 15, 1609-1618. https://doi.org/10.6113/JPE.2015.15.6.1609.

[22] Chang Y-H \& Wu K-W (2014), A gain/efficiency-enhanced bidirectional switched capacitor dc-dc converter. International Journal of Circuit Theory and Applications. 42, 468-493. https://doi.org/10.1002/cta.1863.

[23] Mahery HM \& Babaei E (2013), Mathematical modeling of buckboost dc-dc converter and investigation of converter elements on transient and steady state responses. Electrical Power and Energy Systems, 44, 949-963. https://doi.org/10.1016/j.ijepes.2012.08.035.

[24] Tan RHG, Hoo LYH (2015), DC-DC converter modeling and simulation using state space approach. 2015 IEEE conference on Energy Conversion (CENCON), Johor Bohru, 42-47. https://doi.org/10.1016/j.rcim.2009.11.007.

[25] Shiau J-K \& Cheng C-J (2010), Design of a non-inverting synchronous buck-boost dc/dc power converter with moderate power level. Robotics and Computer-Integrated Manufacturing. 26, 263-267.

[26] Jung D-Y, Hwang S-H, Ji Y-H, Lee J-H, Jung Y-C \& Won C-Y (2013), Soft-switching bidirectional dc/dc converter with a lc series resonant circuit. IEEE Transactions on Power Electronics, 28 , 1680-1690. https://doi.org/10.1109/TPEL.2012.2208765.

[27] Ismail EH, Fardoun AA \& Zerai AA (2014), Step-up/step-down dcdc converter with near zero input/output current ripples. International Journal of Circuit Theory and Applications, 42, 358-375. https://doi.org/10.1002/cta.1856.

[28] Banu JB, Moses M.B \& Rajarajacholan S (2016), A non isolated bidirectional dc-dc converter with lcd snubber. Revista Tecnica De La Facultad De Ingenieria Universidad Del Zulia, 39(1), 131-143.

[29] Pavlovsky M, Guidi G \& Kawamura A (2014), Buck/Boost dc-dc converter topology with soft switching in the whole operating region. IEEE Transactions on Power Electronics. 29, 851-862. https://doi.org/10.1109/TPEL.2013.2258358. 